\title{
Editorial
}

\section{Joint-Use Libraries: Thinking Out of the Box}

In a sense, the joint use of libraries by different types of patrons is not new. Since their beginning, public libraries have been serving all community constituents. Libraries serving both schools and the public have been with us for decades. These endeavors have generally been straightforward in nature and meaning.

In recent years, "joint-use libraries" have taken on a different meaning and a higher level of complexity. This is particularly true for the joint-use facilities serving academic and public constituents. Examples of one library serving both an academic institution and a public constituency include the Point Park College and the Carnegie Public Library, in Pittsburgh; San Jose State University and the City of San Jose (California); and the Nova Southeastern University and Broward County (Florida) Public Library. It is uncommon to find any two joint-use libraries that are identical in the way they operate. For instance, the Point Park College-Carnegie Public Library serves a private college and a public library. Point Park College provides the library space and the Carnegie Public Library manages the facility (e.g., staffing, processing of materials). The San Jose State University-City of San Jose are two public entities dependent on funding from the public trough; the joint facility, when built, will have a single technological infrastructure. Nova Southeastern University is a large private university located in the central part of Broward County. Broward County is providing funds to cover 50 percent of the construction costs of the joint-use library (to be built on the NSU campus) and 40 percent of the annual operating expenses of the

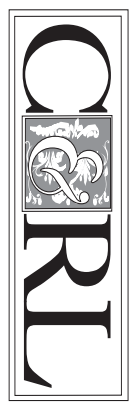
shared facility. Nova Southeastern University will be in charge of the facility, and the staff employed by the funds provided by Broward County will become employees of the university. These are only three examples of academic-public joint-use libraries, and they are not intended to be inclusive.

\section{Realizing More from Collective Efforts}

The decision to engage in a joint-use library partnership is made for a number of reasons, including economies of scale, cost savings, efficiencies, greater depth/ breadth in the collection, and improved services. Joint-use libraries can realize more via collective efforts than they can through independent efforts. The quality and quantity of services, for example, can increase dramatically for both constituents. Two entities can build a larger library than a single entity can.

Evolving technology is providing fodder for the case for more joint-use libraries. Shared databases, computing labs, multimedia centers, teaching/earning and literacy classrooms, and compressed video centers are examples of components that can be shared in a joint-use academic-public library. The days are over when any library can lay claim to having its own crown jewels. The emphasis has to be more focused on improving services, rather than boasting about a library's inventory count. Sharing a single library between two or more entities certainly makes good sense, particularly when one considers how best to offer more and better services for the users. 


\section{Change, Anxieties, and Resistance}

Charles Handy stated: "Those who are always learning are those who can ride the waves of change and who see a changing world as full of opportunities. They are the enthusiasts and the architects of new ways, forms, and ideas." ${ }^{11}$ Joint-use libraries bring with them notable changes in procedures, policies, and practices. They offer common problems and uncommon solutions. Academics will question how the joint-use library will affect the mission of the institution. C. James Schmidt believes the mission of the San Jose City Library and the mission of the San Jose State University Library are more similar than many believe. ${ }^{2}$ Public library proponents will question the commitment of academic librarians to providing necessary services for the public.

Challenges and opportunities should receive the emphasis, not problems and negative perspectives. Evidence from joint-use libraries shared by schools and the public sector reveals that the mutual benefits received by both entities far outweigh the negative aspects. These success stories stress the "oneness" approach over the "we and they" perspective.

\section{Explicit Agreements}

Joint-use library agreements remind me of Robert Frost's "good fences make good neighbors." Writing a good, comprehensive joint-use library agreement makes good library partners! One cannot overemphasize the importance of the joint-use agreement. Of course, lawyers for each constituent must be involved in developing the agreement. And the agreement must be endorsed by individuals at the highest level of commitment (e.g., president of institution of higher education and president of governing board of the public library). A memorandum of understanding (addressing operational aspects of the joint-use library) should be formulated after the agreement. These very important documents represent a relationship built on trust and aimed at maximizing the mutual benefits for both parties.

\section{What to Expect in the Future}

Joint-use libraries will become more common in the twenty-first century. They make sense, have the capacity to give better service, and can provide more resources than an individual library can provide by itself. Overcoming self-interest, anxiety, fear of the unknown, and reluctance to engage in transformational thinking will be the major challenges facing shared facilities. Technology will certainly be a useful tool in making the goals and objectives of joint-use libraries achievable. Some joint-use libraries will take a leadership role in offering the nucleus for an electronic village. Future "town-and-gown" collaborations will be energized by the example offered by the joint academic-public library.

Joint-use libraries offer an opportunity to break away from habit and begin thinking creatively. They encourage leadership in the introduction and implementation of a new order of things. In sum, Oliver Wendell Holmes stated it best: "The human mind, once stretched to a new idea, never goes back to its original dimensions."

DONALD E. RIGGS

Editor

\section{Notes}

1. Charles Handy, The Age of Unreason (Boston: Harvard Business School Review, 1989), 58.

2. Ilene Rockman, "Joint Use Facilities: The View from San Jose. An Interview with C. James Schmidt," Library Administration E Management 13 (spring 1999): 64-67. 